\title{
НЕДОСТАТКИ СИСТЕМЫ ОРГАНИЗАЦИИ БУХГАЛТЕРСКОГО УЧЕТА И ОТЧЕТНОСТИ В ФИНАНСОВО-ХОЗЯЙСТВЕННОЙ ДЕЯТЕЛЬНОСТИ ЭКОНОМИЧЕСКОГО СУБЪЕКТА
}

\author{
(c) 2021 Шлычков Дмитрий Сергеевич
}

кандидат экономических наук, доцент, доцент департамента Аудита и корпоративной отчетности Финансовый университет при Правительстве Российской Федерации, Россия, Москва

E-mail: sds457@mail.ru

\section{(c) 2021 Баутин Александр Георгиевич}

студент Юридического факультета, департамента Международного и публичного права Финансовый университет при Правительстве Российской Федерации, Россия, Москва

E-mail: mega.bautin@mail.ru

В настоящей статье рассматриваются основные подходы к формированию бухгалтерской отчетности деятельности экономических субъектов, а также недостатки системы организации учета в их деятельности. Рассматриваемые подходы позволят сформулировать ряд проблем, возникающих при подготовке отчетов финансово-хозяйственной деятельности и нивелировать риски путем выработки рекомендаций.

Ключевые слова: бухгалтерский учет, бухгалтерская (финансовая) отчётность, нормативный акт, инвентаризация, достоверность, документооборот, учет

В современных условиях рыночной экономики и постоянного совершенствования финансово-хозяйственной деятельности участников рынка, усиливается роль и значение бухгалтерского учета. В свою очередь с ростом потребности в бухгалтерском учете, возрастает рост бухгалтеров, а, следовательно, возрастает спрос и требования. Бухгалтер двадцать первого века - это не просто «клеточник», который записывает значения одной клетки в другую, это специалист, который видит за цифровыми показателями экономический смысл и влияет на финансово-хозяйственную деятельность организации. Данный функционал со стороны бухгалтера можно назвать хозяйственным учетом, который подразделяется на: оперативный учет, статистический учет и бухгалтерский учет, о которых мы погорим далее.

Организация бухгалтерского учета - система условий и элементов построения учетного процесса с целью получения достоверной, своевременной информации о хозяйственной деятельности организации и осуществления контроля за рациональным использованием производительных ресурсов и готовности продукции. Данное определение следует из требований к бухгалтерскому учету, которые закреплены в ст. 13 Федерального закона от 06.12.2011 № 402-Ф3 (ред. от 26.07.2019) «О бухгалтерском учете» (далее - № 402-Ф3) и п.п. 6,7 Положения по бухгалтерскому учету «Бухгалтерская отчетность организации» (далее - ПБУ 4/99). Организацию бухгалтерского учета справедливо рассматривать как систему, включающую в себя набор элементов, каждый из которых самостоятелен в процессе финансово-хозяйственной деятельности. Это такие элементы как:

- Первичный учет;

- Документооборот;

- Инвентаризация;

- План счетов бухгалтерского учета;

- Формы бухгалтерского учета;

- Формы организации учетно-вычислительных работ;

- Объем и содержание отёчности.

На основании данных элементов формируются определенные требования, предусмотренные ст. 13 Закона № 402-ФЗ:

- Бухгалтерский баланс

- Отчет о финансовых результатах

- Отчет о движении денежных средств

Значимость данных требований очень высока, неслучайно аудиторы при формировании мнения о достоверности всей бухгалтерской финансовой отчетности анализируют именно эти требования.

Начиная с 2013 года все экономические субъекты обязаны вести бухгалтерский учет в 
соответствии с законом № 402-Ф3 и ст. 23 Налогового кодекса, которая закрепляет обязанность ведения бухгалтерского учета в целях исчисления налоговой базы. Каждый субъект экономической деятельности обязан подавать годовую бухгалтерскую отчётность, согласно законодательству, в налоговую службу и в органы статистики. При этом существует ряд субъектов, которым сдача бухгалтерской отёчности не требуется, в их числе: индивидуальные предприниматели и организации, созданные в соответствии с законодательством иностранного государства [1].

Соблюдение всех требований является гарантом безопасности для налогоплательщика и ответственных лиц. Однако, некоторых субъектов не останавливает уголовная, административная и гражданско-правовая ответственность за нарушения бухгалтерской отчётности, а вследствие этого и налоговой. Яркими примерами является: сокрытие налогов и занижение налогооблагаемой прибыли. По данным статистики налоговых органов лишь около 18\% всех экономических субъектов своевременно и в полном объеме рассчитываются по налоговым обязательствам, около 50\% осуществляют свои конституционные обязанности по уплате налогов в неполной мере и около 29\% не осуществляют совсем [2]. Основные нарушения налогового законодательства выявляются в тех областях, где высоки требования для бухгалтерской отчётности, а именно алкогольная, автомобильная, нефтедобывающая, металлургическая и другие промышленности [3].

Причинами налоговых нарушений являются:

- нестабильная экономическая ситуация

- чрезмерное налоговое бремя

- недостаточная функциональность отдельных налоговых механизмов, касающихся совокупности правовых норм, обусловливающих порядок исчисления и уплаты определенного налога

- несовершенство законодательства.

Анализируя бухгалтерскую отёчность, где содержится информация, свидетельствующая об эффективности организации, можно заметить ряд пробелов:

1) отражаемые показатели в отчете о финансовых результатах отражаются за два отчетных периода (текущий и прошлый отчетный период), а данные бухгалтерского баланса - на три отчетные даты, то есть изменения данных видно за три отчетных периода. Следовательно, нарушается принцип сопоставимости экономического анализа. Кроме показателей сопоставимости, данная проблема может вызвать ряд проблем в виде дополнительной управленческой отчётности по факту изменения в сторону уменьшения чистых активов экономического субъекта над его уставным капиталом [4]. Еще один вопрос возникает к пояснительной записке к бухгалтерскому балансу, где детализация раскрываемых статей бухгалтерского баланса дается за два отчетных периода (текущего и прошлого). Решением данной проблемы может служить: возврат к системе, когда в бухгалтерском балансе отражались данные за два отчетных периода или привести в соответствие все формы бухгалтерской отчетности к трем отчетным периодам.

2) следующей проблемой относительно форм бухгалтерской отчётности является квартальный бухгалтерский отчет. В бухгалтерском балансе показываются данные за три смежных отчетных периода (например, баланс за первый квартал 2019 года отображает данные на 31.03.2019, 30.09.2018 и 31.12.2018), однако отчет о финансовых результатах представляет данные за два отчетных (квартальных) периодов, то есть на 30.03.2019 и 31.12.2018. Данные сведения не позволяют проанализировать динамику в силу несопоставимости, потому что можно взять только 31.03.2019. Данный пробел затрудняет работу, увеличивая объем документооборота и процесс его подготовки. Примером такой трудности могут служить коммерческие банки, которые требуют проводить анализ по 3-5 смежным кварталам. По мнению автора выходом из данной ситуации может служить унифицированные временные измерения за 5 смежных кварталов по бухгалтерскому балансу и отчету о финансовых результатах. Рациональным зерном в данном предложение является то, что отчет о финансовых результатах отражает накопительные данные, в связи с этим, объективно скорректировать данные за первый с четвертым кварталом не представляется возможным (особенно это касается сезонных отраслей где велик риск обстоятельств непреодолимой силы, например, сельское хозяйство). Сведения об имуществе, капитале и активах за 5 смежных периодов будет способствовать быстрому отслеживанию динамики изменений статей бухгалтерского баланса - итерационным путем.

В целом, имеющиеся квартальные формы бухгалтерской отчетности, не являются инфор- 
мативными и не дают возможность объективно спрогнозировать финансовое состояние организации,- это одна из проблем увеличения банкротства предприятий.

Другой частной проблемой является учет дебиторской задолженности. Экономические субъекты нередко частично отображают информацию о наличии у них дебиторской задолженности на определённую дату, о просроченной задолженности и неправильно отображают дебиторскую задолженности на счетах бухгалтерского учета.

Решением данной проблемы может служить упрощение форм учета, а также ужесточение административной ответственности в отношении субъектов.

Наряду со всеми проблемами главной и первостепенной является бизнес-процесс документооборота, как элемента бухгалтерского учета. Проблематика документооборота прежде всего связана с развитием цифровизации и усложнением технологических процессов. Если раньше документооборот велся в письменном виде, а именно на бумажном носителе, то сейчас процесс осложнён электронными документами, регулирование которых ведется не всегда.

В соответствии с п.6 статьи 10 ФЗ №402 регистр бухгалтерского учета составляется на бумажном носителе и (или) в виде электронного документа, подписанного электронной подписью. При это регламентировать процесс документооборота возможно разными способами: графиком документооборота, инструкциями по документообороту, положениями о документообороте, в частности инструкции используются в большом количестве государственных структур, например, Приказ Генерального прокурора № 45, Приказ Росархива № 44, Приказ Судебного департамента при Верховном Суде РФ № 36 и другие. Что касаемо бизнеса, то в большинстве своём документооборот регулируется графиком, благодаря графику документооборота можно назначить ответственных за составление и передачу документов лиц, а также установить конкретные сроки по передаче первичных документов в бухгалтерию. Это позволит бухгалтеру получать документы вовремя. В настоящий момент отсутствует единая форма графика или инструкций, что безусловно затрудняет работу между государственными органами, усложняет работу бухгалтерам и в целом вызывает инфляцию правовой материи. Например, в бухгалтерском и налоговом учете кредиторскую задолженность перед ликвидированным поставщиком нужно списать в доходы на дату внесения в ЕГРЮЛ записи о его ликвидации [5]. Следить за процессом ликвидации контрагента обязанности у бухгалтера нет, значит донести информацию должен тот работник, в чьи компетенции это входит. Также важным будет указать сроки сдачи документов по командировкам, в соответствии с п.26 Постановления Правительства Российской Федерации обязанностью работников является отчет в трехдневный срок после окончания командировки. Важность данного введения заключается в том, что работники часто забывают о данной процедуре. Что касаемо оформления графика, то он может быть в виде текста, таблицы или схемы. Важным фактом является то, что готовый график должен утвердить и ввести в действие генеральный директор своим прика30м.

Возвращаясь к электронному документообороту, самой распространённой классификацией является деление на неформализованные и формализованные документы. Если с первыми все понятно, это документы, которые регулируются правовыми обычаями и локальными приказами руководителей организаций, то с формализованными иначе. К таким документам относятся: электронные счета фактуры [6], документы о передаче результатов работ (оказании услуг) в электронной форме [7], документы о передаче товаров при торговых операциях в электронной форме (например, ТОРГ-12) [8].

В настоящий момент существует два способа электронного документа оборота: привычный для всех, через электронную почту и второй вариант, через оператора электронного документооборота. Большая часть представителей бизнеса использует первый способ в силу простоты и консерватизма. Ведь требования для операторов довольно высоки и большинство налогоплательщиков боятся, что, нарушив строгие правила оформления и ведения электронных документов последует ответственность, предусмотренная п.3 статьи 120 Налогового Кодекса.

Хочется отметить, что Государственная Дума с 1 апреля 2020 года планирует ввести эксперимент с электронными кадровыми документами, где работодатели будут вправе выбрать:

- какие документы переводить в электронный формат (кроме трудовых книжек);

- кто будет участвовать (все работники или 
отдельные структурные подразделения);

- какую информационную систему использовать (собственную или сервис «Работа в России»).

Сотрудники смогут в любой момент отказаться от ведения документов в электронном виде, письменно уведомив об этом работодателя.

Наряду с этим в настоящий момент в Министерстве Финансов разрабатывается проект федерального стандарта бухгалтерского учета «Документы и документооборот в бухгалтерском учете», который должен поставить точку в данном вопросе.

Итак, можно отметить, что современная бухгалтерская система имеет ряд значительных изъянов, которые затрудняют ведение финансово-хозяйственной деятельности субъектов. Хочется отметить, что существует ряд законодательных пробелов, с которыми судебная практика совместно с бизнесом вырабатывают свои доктринальные, то есть прецедентные нормы, в частности это очень хорошо заметно в области электронного документооборота. Согласно фабуле дела: одна компания требовала от контрагента более 115 миллионов рублей за переданный товар и проценты [9]. Арбитражный суд города Москвы вынес решение в пользу продавца, который по словам суда представил в суде накладные, которые были в электронном документообороте с цифровыми подписями, как это было обговорено контрагентами, а другая сторона, то есть покупатель не смог доказать оплату товара. Суд, ссылаясь на ч. 5 ст. 9 Ф3 № -402 посчитал, что электронная накладная, является подтверждением доставки груза. При этом важно отметить, что электронный документ в форме отчета поставки, обладает юридической значимостью, но не имеет юридической силы, что не дает возможности приходовать товар и отра- жать состояние расчетов, а вследствие этого не влечет правовых последствий, как обязанность отражать задолженность за товар.

По мнению автора, предполагается, что в 2020 году система бухгалтерского учета в цифровом поле вырастет. Это связанно с поправками в Налоговый кодекс РФ, а именно с ведением дополнительных налогов и все большей цифровизацией для удобства, ускорения ведения финансово-хозяйственной деятельности экономических субъектов. Ведь на данный момент бухгалтерский учет развивается в направлении более точного отражения результатов деятельности, а налогообложение базируется на данных именно бухгалтерского учета [10]. Об этом свидетельствуют последние новости, где в уставный капитал ООО «Артель», генеральным директором которого является Михаил Успенский был внесен Bitcoin [11], а это уже совершенно новый виток для бухгалтерского учета. В современной отечественной практике - это совершенно новый подход, регулирование которого отсутствует. Для того чтобы внести криптовалюту в уставный капитал, была проведена независимая оценка электронного кошелька, затем было проведено оформление акта приема-передачи логина и пароля от электронного кошелька и заверение нотариусом. Интересным фактом являются бухгалтерские проводки при учете криптовалюты на баланс организации, потому что методики и регулирования в настоящий момент нет. По мнению автора, если происходит покупка криптовалюты через рубли, то при составлении проводок будут указаны: Д58 К76 - покупка криптовалюты; Д76 К51 - оплата криптовалюты, а в случае майнинга [12] - Д58 К91-1. Подводя итог, хочется сказать, что законодатель не стоит на месте и совсем скоро будет выработана правоприменительная практика в данной области.

\section{Библиографический список}

1. Закон Российской Федерации «О бухгалтерском учете» от 06.12.2011 № 402 // Российская газета. Ст. 6

2. Алайкина Л.Н., Котар О.К., Исаева Т.А. Методы управления налоговым риском на предприятиях сельского хозяйства // Успехи современной науки и образования. // Успехи современной науки и образования.2016. - № 4.- С. 92-99.

3. Преодоление финансового кризиса перерабатывающими предприятиями апк саратовской области / Н.И. Кузнецов и др.,- 2009: Саратовский государственный аграрный университет им. Н.И. Вавилова, Саратов.

4. Закон Российской Федерации «Гражданского кодекса РФ (часть первая)» от 30.11.1994 № 51 // Российская газета.-Ст. 90 
5. Приказ Министерства финансов РФ «Бухгалтерская отчетность организации» (ПБУ 4/99)» от 06.07.1999 № 43 н п. 6

6. Приказ Министерства финансов РФ от 10.11.2015 № 174н

7. Приказ Федеральной налоговой службы РФ от 30 ноября 2015 г. № MMB-7-10/552@

8. Приказ Федеральной налоговой службы РФ от 30 ноября 2015 г. № ММВ-7-10/551@

9. Ефименко Е. Недостоверно или удостоверено: электронные документы в судебной практике [Электронный ресурс] / Е. Ефименко. - Режим доступа: https://pravo.ru/review/view/133826.

10. Основные изменения налогового законодательства в 2020 году [Электронный ресурс]:- Режим доступа: http://www.consultant.ru/document/cons_doc_LAW_332619/

11. Bitcoin впервые внесли в уставной капитал российской компании [Электронный ресурс] // РБК - Режим доступа: https://www.rbc.ru/crypto/news/5ddbc3779a7947b7a56880cb

12. Законопроект № 419059-7 «О цифровых финансовых активах, цифровой валюте и о внесении изменений в отдельные законодательные акты Российской Федерации» Майнинг - деятельность, направленная на создание криптовалюты и/или валидацию с целью получения вознаграждения в виде криптовалюты. Майнинг признается предпринимательской деятельностью в случае, когда лицо, которое его осуществляет, в течение трех месяцев подряд превышает лимиты энергопотребления, установленные Правительством Российской Федерации. 